\title{
Puritan In Lust: The Infidelity Of The Symbol A In The Scarlet Letter
}

\author{
Fibrianni Pertiwi ${ }^{1}$, Fatma Hetami ${ }^{2}$ \\ \{pertiwifibrianni@gmail.com¹, fatmahetami@mail.unnes.ac.id² \\ English Department, Faculty of Languages and Arts, Universitas Negeri Semarang ${ }^{1}$
}

\begin{abstract}
This paper aims to point out the infidelity of Literature-to-film adaptation The Scarlet Letter. We attempt to comprehend the different meaning of symbol "A" that comes up within the film adaptation. We believe that it is influenced by the idea of entertaining a large audience which led the film to show lots of romance scenes which ended with a happy love life. We applied textual and intertextual analysis to explore both novel and film. We employed Peirce "semiotic theory to analyze how symbol "A" works in both novel and film adaptation to shape its meaning. Our study reveals that on the one hand symbol "A" represents "Adultery"; on the other hand, it represents "Ability". Nonetheless, the film adaptation has its own way in revealing the meaning of symbol "A" becomes "Ardor". Using comparative analysis, we found out that the film is unfaithful and straying away from the novel; lust has dominated the film.
\end{abstract}

Keywords: Puritan, lust, semiotic, Ardor, literature-to-film adaptation, The Scarlet Letter

\section{Introduction}

Adapting material previously published in another medium is something that many of the film industries have been doing. Even though the film industries are not the first one that invented it, it is safe to say that filmmakers have been adapting from novels since the very beginning of film. It is proven that in 1915, Trilby and Little Billee became the earliest surviving film adaptation which was previously Trilby and Little Billee novel was adapted into a play in 1896. Up to the present time, there are many novels that have been made into films. Film adaptation or literature-to-film adaptation is the adapting medium of literary works into a medium of film or the transfer of a story to a feature film.

Snyder (2011) states that film adaptation is the combination of two mediums or he expresses it as a marriage of media. In line with this Snyder also says that, "how the combination of two

\footnotetext{
${ }^{1}$ Fibrianni Pertiwi

${ }^{2}$ Fatma Hetami
} 
different mediums is like a marriage; it is two but also one, which creates a "dyadic" union of sorts that extends its own benefits ${ }^{3}$." (1)

Nonetheless, this literature-to-film adaptation creates pros and cons regarding the fidelity of the film. For those who are from a literary background, straying away from novel is considered a great betrayal especially novel that is categorized as a 'classic'. However, from the perspective of the film industry, there are many things that should be adjusted to the market needs. Stam in Snyder (2011) says that this kind of consideration is "a subliminal form of class prejudice, a socialized form of guilt by association ${ }^{4}$." (1)

Further, Stam in Snyder (1) explains that, "According to Sam, since the film audience is more popular and it has a massive audience, this automatically is seen as degrading and the respect it warrants. Literature gets that reverence due to its very nature and tradition. And so, adaptations then "is made just to satisfy an audience with its light and lovely story rather than a beauty of literature" (1). In other words, it can be inferred that the process of the adaptation is influenced by the ideology of entertaining a large audience and following mainstream expectations. For this reason, The Scarlet Letter film adaptation is made with a lot of romance scenes which ended with a happy love life.

The Scarlet Letter is a novel that was written by Nathaniel Hawthorne and published in 1850. The novel brings us back to the $16^{\text {th }}$-century which tells us the story of Hester Prynne after she committed adultery and how she survived and carried on her life even in a desperate situation. The punishment she had to bear was wearing an embroidered badge of letter ' $\mathrm{A}$ ' on her bosom forever until the end of her life. The novel shares a complex yet interesting plot for there is only one main problem which draws many conflicts into the story. The novel includes a few matters such as adultery, hypocrisy, revenge, alienation, love triangle, etc. Hawthorne also told his deep thought about Puritan's strict religious ways in his book as an important role in the story ${ }^{5}(2)$. Hawthorne seemed to have felt guilt for the sins of his ancestors, which made him create "The Scarlet Letter " novel to show that Puritan had lost much of their devotion to the religion (3).

In 1995, The Scarlet Letter was adapted into a film with the same title which was directed by Rolland Joffé and it is 135 minutes long film. This film received negative reviews because it turned into rated R film for its violence, rape, gore, sex, and nudity. It became trashy, sensual, and lustful at first sight. The film even became "Worst remake or sequel" in the Golden Raspberry Award 1995 ceremony.

\footnotetext{
${ }^{3}$ See Snyder (2011) to read complete explanation about a marriage of media.

${ }^{4}$ See Snyder (2011) to seek full information about the roots of a prejudice.

${ }^{5}$ Hawthorne N. The Scarlet Letter United State of America: THE NEW AMERICAN LIBRARY OF WORLD LITERATURE; 1959.
} 


\section{Review of Related Literature}

Before conducting this paper, the researchers made some review of related literature which consisted of previous studies, semiotic theory by Charles Sanders Peirce, and literature-to-film adaptation (infidelity). It is presented as the following:

\subsection{Previous Studies}

Some previous researches about The Scarlet Letter have been carried out. The first article was written by Isaoglu in 2015 entitled A Freudian Psychoanalytic Analysis of Nathaniel Hawthorne's The Scarlet Letter. According to Isaoglu (4), this research is about analyzing the main characters of The Scarlet Letter by employing Sigmund Freud's Psychoanalysis to reveal how these characters' lives and how their personalities are formed. The result shows that the effect of id, ego, and superego on their personalities are caused by their repressed childhood and past memories. ${ }^{6}(4)$

Different from Isaoglu, Wang in 2010 conducted a research which focused on Hester Prynne's new image that emerged within the novel. His paper entitled A Representative of the New Female Image-Analyzing Hester Prynne's Feminist Consciousness in The Scarlet Letter, tried to find a new female image of Hester by using feminist theory. The researcher analyses the data by classifying into two points, such as Hester's rebellion spirit and Hester's self-reliance. From the analysis, Wang (5) found out that the way Hester reacted to the patriarchal system that Puritan society has, reflects her feminist consciousness to the abnormal rules created by men. This action of Hester shows that there is another image or another character that Nathaniel Hathorne wanted to portray from Hester Prynne. ${ }^{7}$ (5)

Another previous study is conducted by Sang (2010) with the title An Analysis of Hester's Hypocrisy in The Scarlet Letter. This research attempts to find the real character of Hester Prynne. The researcher uses psychoanalytical criticism to conduct the analysis. By classifying the data, which are Hester's deep thoughts and Hester's attitude towards the Scarlet Letter "A" and Dimmesdale, the researcher finds out that Hester Prynne is a hypocrite woman. The way she thinks and the way she does are completely different. She is always thinking about the unequal role of women in society, she wants to reconstruct the system which rules society; yet there is no action. All she did was just obey them without any attempt to deny them ${ }^{8}$. (6)

Different from the research above, this one is conducted by Magfirah (2017) entitled Analyzing Social Aspects in The Scarlet Letter Novel by Nathaniel Hawthorne (A Generic Structuralism Approach). This research is about the social aspects in the novel by employing a generic structuralism theory. The result finds out that there are five social categories as the following: family, tradition, education, religion, and economy ${ }^{9}$. (7)

Lastly, a research called A Comparative Analysis of The Scarlet Letter from Fiction to Movie was conducted by Zhang in 2017. This research dealt with comparing both the novel and the

\footnotetext{
${ }^{6}$ See Isaoglu (2015) to get more information about a Freudian Psychoanalytic of The Scarlet Letter.

${ }^{7}$ See Wang (2010) to know about his analysis of Hester Prynne's Feminist Characters.

${ }^{8}$ See Sang (2010) to fully understandabout Hester's Hypocrisy.

${ }^{9}$ See more about Magfirah's (2017) analysis.
} 
film of The Scarlet Letter to find the differences in the film adaptation from its original text; novel. The researcher found out that there are several points which had a change for instance, the theme, the language in the movie text, the character portrait, and the imagery ${ }^{10}$. (8)

Unlike those previous studies above, this paper entitled Puritan in Lust: The Infidelity of The Scarlet Letter aimed to point out the possibility of another meaning of symbol "A" that emerged within the story in both the novel and the film of The Scarlet Letter in order to prove the infidelity of literature-to-film adaptation of The Scarlet Letter through Charles Sanders Peirce's theory of semiotics. Textual and intertextual analysis were needed to explore both The Scarlet Letter novel and its film adaptation. By employing Peirce 'semiotic theory, the researchers found out that both novel and film had their own way of portraying the symbol ' $\mathrm{A}$ '. In the novel, on the one hand, symbol 'A' represents 'Adultery', on the other hand it represents 'Ability'. Yet, the film showed that on the one hand it refers to 'Adultery', on the other hand it refers to 'Ardor',

\subsection{Semiotic Theory (Charles Sanders Peirce)}

Semiotic derives from the Greek semesion which means sign. Generally, semiotics is the study of how sign is created and grasped.According to Leeds-Hurwitz (9) in Halina and Andreas (2014), Charles Sanders Peirce proposes semiotics is similar to the idea of logic that is centered on the knowledge of human thinking process (10). Further, Leeds-Hurwitz (1993) in Halina and Andreas (2014) also says that, "logic is just a different term of semiotics ${ }^{11}$ ““ (10)

Charles Sanders Peirce began writing on semiotics in the 1860s. According to Peirce (1931) in Chandler (2000), Peirce proposes a triadic model of sign as the following: the sign (representamen); the form which sign takes (not necessarily material), an object; to which the sign refers, and an interpretant; not an interpreter but rather the sense made of the sign (11). Thus, this process of triadic relationship is called semiosis. Peirce's view of semiosis integrates all the components of semiotics such as syntax, semantic, and pragmatic. Syntax is the domain of the representamen which means the formal or structural relations between signs; semantics is "the domain of object which means the relationship of signs to what they stand for; and pragmatics is the domain of interpretant which means the relation of signs to interpreters". (12)

Thus, to analyze a text by employing this theory, there are few steps that can be done. First, decide the 'Firstness' of the text or the representamen of the thing that wants to be analyzed. Then, the 'Secondness' or the object, and lastly the 'Thirdness' or the interpretant.

\footnotetext{
${ }^{10}$ See Zhang (2017) to fully understand about a comparative analysis of The Scarlet Letter

${ }^{11}$ See Leeds-Hurwitz's (1993) explanation about Logic in Halina and Andreas (2014)
} 


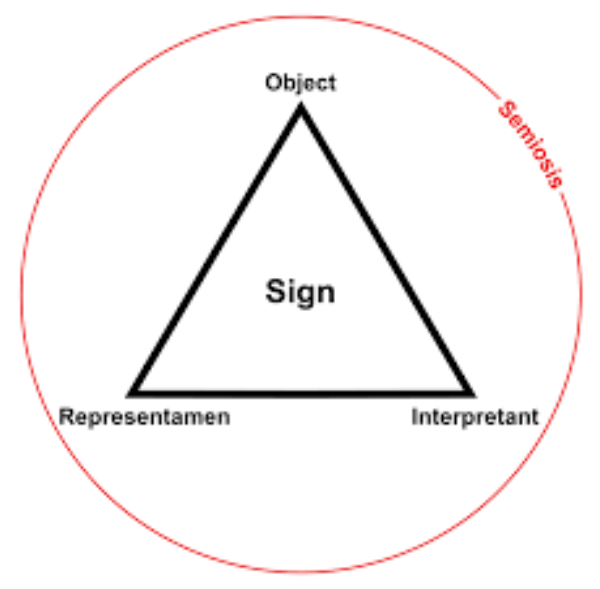

Fig 1. A Triadic Model of Sign

\subsection{Literature-to-film Adaptation (Infidelity)}

Literature-to-film adaptation analysis is an endless debatable subject. Because it requires an intertextual comparison, it is unfortunate that this idea of comparative analysis will end up with the question of which one is better. Certainly, it will fuel the anger of both literary scholars and film scholars. Because on the one hand, literary scholars seem to indicate disagreement of literature -to-film adaptation analysis however, on the other hand film industry believes that they could interpret a novel in a beautiful way for its visualization.

Snyder (1) states,

And as I was reading, I felt like I was in the middle of the battlefield - the literary enthusiasts. . . on one side proclaiming it impossible to adapt a novel of intense rigor and rife with meaning into film, particularly a commercial film. . . and the film scholars on the other side, claiming how well a film can translate novel, of any quality, especially those of the best quality, into an artistic masterpiece ${ }^{12}$. (1)

Therefore, Snyder (2011) provides five critical approaches to the literature-to-film adaptation that are still under the idea of intertextual comparison as the following: adaptability analysis, adaptation process analysis, fidelity/infidelity analysis, specificity analysis, and audience reception anxiety analysis (1). For this research, the researcher used an infidelity analysis as it fitted the objective of the expected analysis.

Although infidelity analysis was underestimated towards film adaptation theorists and scholars because it seems like the theory is just comparing the two mediums and finding whether it is faithful or not, it actually can be a valuable means to analyze film adaptation. For that reason,

${ }^{12}$ See Snyder (2011) to look more detail the information of literature-to-film adaptation 
Snyder (1) explains that,"this analysis is not meant for criticizing one against the other yet it is to understand why particular events or scenes were added or remain in the film ${ }^{13}$." (1)

\subsection{Comparative Research}

Comparative research is the act of comparing two or more things with a view to discovering something about one or all of the things being compared. (13) Comparative research involves understanding, studying and explaining every aspects or events. Its purpose is to arrive at some conclusions concerning some events that are different from each other. It focuses on the differences between the two subjects and clearly defines the comparative nature of the subjects. So it is clear that in comparative research we compare two things or finding their differences or both.

\section{Methodologies}

There are two methodologies that were used to analyze this research which are a semiotic approach by Peirce and comparative analysis. Basically, the first step that the researchers did was analyze each object by employing a semiotic approach to find the meaning of the sign which appeared in both stories. The next step is finding the representamen, then the object and lastly the interpretant. After knowing the meaning of the sign in both the novel and the film, the researchers compared it to see whether it is different or not and how it is different.

\section{Discussions and Findings}

As we knew that semiotics concerned with signs, the first thing to do was to know what sign did appear in The Scarlet Letter. The obvious sign the researchers found out in the story was the sign of ' $A$ ' which refers to 'Adultery'. It was true because meaning created when there was a circumstance. Thus, in the story, Hester Prynne has an illegitimate child which leads her to have an embroidered badge of letter ' $A$ ' on her bosom as a physical reminder of her sin that she was an adulterer.Nonetheless, the researchers argued that there was another meaning or representation of symbol 'A' besides 'Adultery' as the following:

\subsection{Ability}

To fully understand about another meaning that emerged within the story, the researchers explained another circumtance which caught the attention of the researchers. It was when Hester from the beginning of the novel, turned into a walking symbol of sin. Many townspeople were gossiping about her when Hester was standing in a scaffold being humiliated and they seemed to indicate the disagreement toward the punishment that Hester received. They thought that the magistrates were too merciful and degrading the holy of their religion by giving such an easy punishment. Townspoeple hoped that Hester was given a hot iron on her forehead rather than

\footnotetext{
${ }^{13}$ See Snyder (2011) and his book for more understanding about infidelity criticism.
} 
wearing letter ' $A$ ' badge (2) because Hester has brought shame upon all people out there, they wanted her to die as well. (2)

After several months Hester had spent at the prison, she was finally released and given the free choices whether she wanted to stay or left Boston. However, she chose to stay because she felt attached to the city which always reminded her of the sin; she did not want to forget that; she wanted to face it and sought people's acceptance. For that reason, she decided to settle at the edge of the town while still being alienated from everyone and living alone with her only daughter, Pearl. She is the perfect example of a broken and sinful woman. Her sin and her disgrace was something that looked as if it had emerged from the ground. (2)

Living alone being an outcast and alienated, Hester established her life and her daughter by working as a tailor. Her skill of needle work was wonderful; she got many orders even from the important people in town who wanted her to sew their fabrics. As the story stepped further into Pearl who was now seven years old, Hester had become more active in society; she was doing good deeds for other people. Hawthorne wrote in his his novel that, "the Puritanic style of dress were mostly were made by her." (2)

Those paragraphs aboves indicated that Hester made an effort on changing people's perspective on her. She did not want to limit herself just because of her label as an adulterer, so she could not do something good. Instead, she did lots of good deeds. She wanted to use her skill in needlework and her good intention of helping people can be useful for others. The letter was her calling for her kindness to be useful for other until people finally forgot that the ' $A$ " was a shame and it changed became something good for Hester; Able. She got those ability to look after people and she changed people's perspective on her. Now, they saw her as a confident and strong woman who was very meritorious for others and became role model for other women. (2)

As the researchers have explained all the text above, the researchers got several points to take such as Hester's effort to be useful for others, what people saw on Hester, and the shifted meaning of symbol ' $A$ '. From those circumstances, the researchers convinced that it was true there was another meaning of "A" other than "Adultery". Hence, by employing Peirce's triadic model of sign; representamen, object, and interpretant, to analyze how another meaning arise within the text, the researchers find that the representamen of the texts above is an embroidered badge of letter " $A$ " stitched in gold and scarlet on Hester Prynne's bosom because that was the form which the sign took (11). Then, because the object is something that was reflected by the sign (9) therefore Hester Prynne who made use of her skill in needlework to support her life with Pearl, distributes food for the poor, takes care for the sick, and many other community services. Lastly, the interpretant which means the significance delivered by the representamen about the object that was unknown in advance (9). The interpretant that was found in the novel is the letter " $\mathrm{A}$ " that stands for "Ability" which is the representation of Hester Prynne. She is able to face and overcome her problem of people's perspective on her who was an adulterer. She proves herself that she could do good deeds as well as other people. 


\subsection{Ardor}

Different from the portrayal of symbol ' $A$ ' in the novel, the film has their own way of revealing the symbol ' $A$ '. All of them started with the signification of 'A' for 'Adultery', yet the film seemed to get carried away by the circumstance of Hester who had been stuck with lust. It happened when Hester Prynne unexpectedly followed a red bird that flew towards the forest; which the researchers believed the bird was the representation of her sexual desire. Upon entering into the forest, Hester unconsciously found a man swimming nude in the river which later she knew that the man was Dimmesdale. Hester looked at him in awe as if looking into something precious in her life. It was when Hester fell in lust with Dimmesdale.

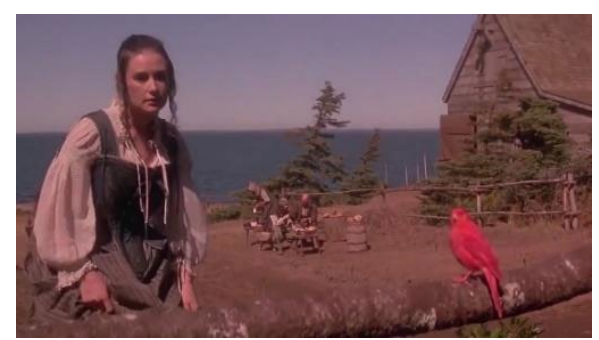

Fig 2. Hester saw a red bird and decided to follow it towards the forest.

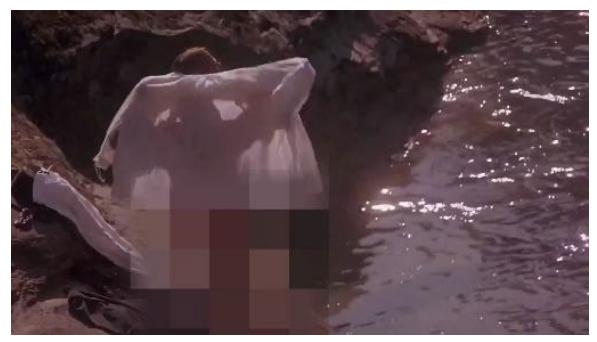

Fig 3. Dimmesdale after he swam on the river

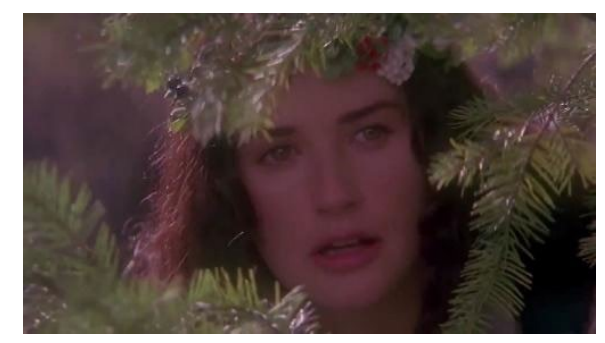

Fig 4. Hester who looked at Dimmesdale in awe

The next scene was when Dimmesdale found out that Hester actually was married. Even though he confessed to Hester that he loved her and he knew that their feelings were mutual, Dimmesdale did not want to keep on what they were doing because he knew that was wrong. They would get hanged for that. He felt that the affairs will put her in danger if they continued to do it. Yet, Hester seemed to ignore it and felt disappointed when Dimmesdale wanted to stay away. Hester thought that what they were doing was fine because they both love each other.

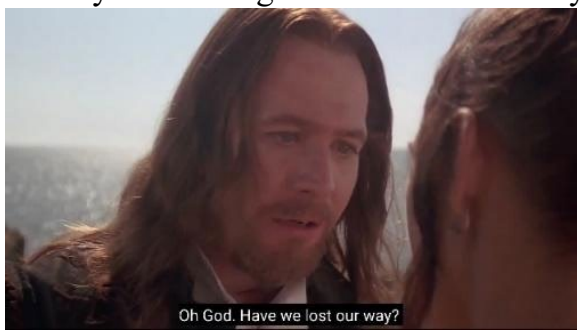

Fig 5. Dimmesdale realization of what they were doing 


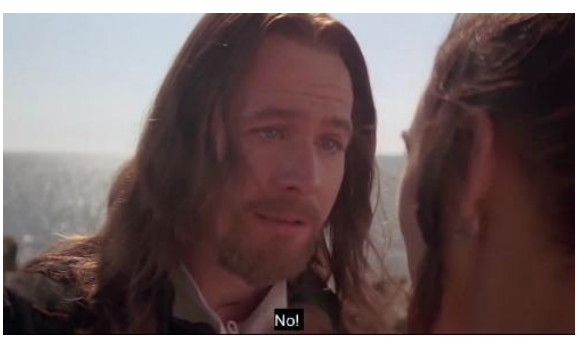

Fig 6. Hester's denial

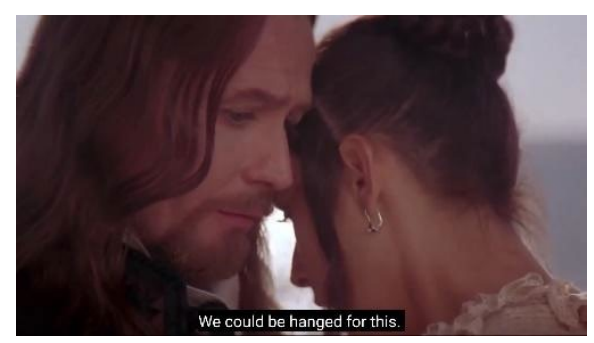

Fig. 7 Dimmesdale's realization of his action

This scene above proved once again that lust which the researchers explained in the first scene is proven right. From lust at first sight, now Hester felt the desire of owning Dimmesdale. Hester should be aware that her husband had not arrived yet, in fact she still had a husband. So, what must Hester take into this consideration? This is no other than lust; this had started to take over into Hester's mind which resulted in the obsession of loving Arthur Dimmesdale.

The third scene was about Dimmesdale who visited Hester's house to tell about her husband which presumably has been dead. Apparently, one of the town ships was attacked by the Indian natives and they found a hat with Hester's husband's name on it. Dimmesdale suspected that Hester's husband was one of the victims of the attack. Oddly enough, Hester who heard the news about her husband felt relieved that her prayer was answered; She was happy knowing her husband was dead. Then, she asked Dimmesdale for how long people had to be mourning. Dimmesdale explained that because there was no proof of a certain death, Hester should wait for seven years until she could appeared in public. However, Hester ignored it and did something wrong; they were kissing and having sexual intercourse afterwards. 


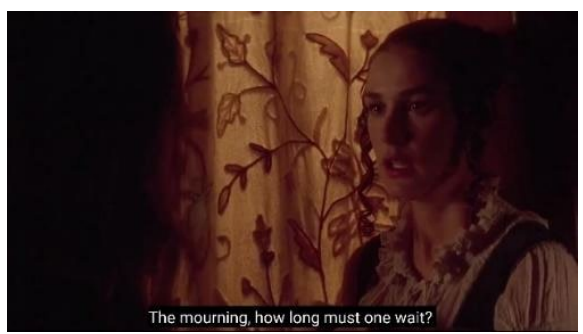

Fig 8. Hester asked about a mourning

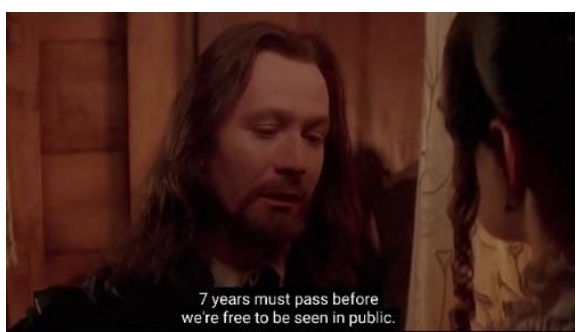

Fig 9. Dimmesdale's explanation about the time for mourning

This third scene above was a strong evidence that lust has finally driven her crazy. Just after hearing about the death of her husband, she immediately decided to have an affair which she knew that it was a big mistake knowing she should be mourning not having an affair. She seemed not to care; instead, she made a reason that it was what she wanted, to be independent.

The fourth scene was after Hester was punished for adultery and should wear an embroidered badgeof the letter ' $A$ '. She was shocked to find that her husband was still alive all along. Her husband; Chillingworth, threatened Hester that he would find her affair and killed him. Hester knew about that, certainly afraid that her husband would do that. Furthermore, Hester asked Dimmesdale to leave the country in order to save himself from Chillingworth.

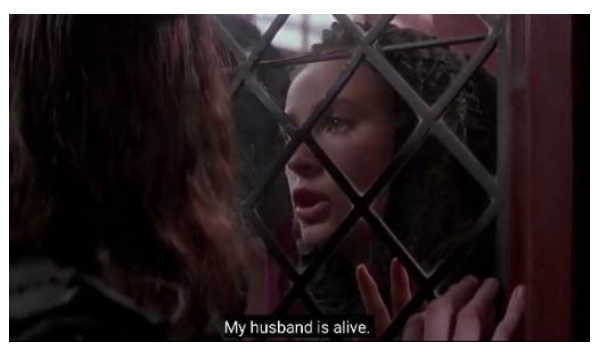

Fig 10. Hester told Dimmesdale about her husband 


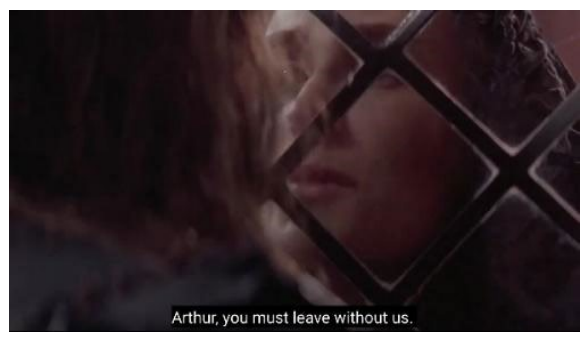

Fig 11. Hester asked Dimmesdale to leave Boston

This scene above proved again the researchers' assumption of Hester's different character from the novel; she was madly in love with Dimmesdale. Unlike its original story, here after being punished standing in a scaffold with letter " $A$ " that she should wear for until the end of her life, Hester seemed preoccupied with the thought of her love life that could not be together because her husband was still alive. In the novel, what preoccupied Hester was the way she felt about the sin, punishment, perspective of others about her, and how to overcome those spectacles and become a good person for others.

The last scene was the ending of the film and it was about Dimmesdale who admitted that he was the father of Hester's daughter as well as he declared that he loved her. After the confession of Dimmesdale it had been confirmed that they will be hanged. Unexpectedly, the native Indian came and attacked townspeople which ultimately resulted in Hester and Dimmesdale could escape from hanging. Luckily, Hester Prynne, Arthur Dimmesdale, and Pearl could escape from the attack and after that they decided to move to North Carolina and live happily ever after until death comes calling Arthur Dimmesdale before Pearl reached her teens. This ending of The Scarlet Letter film adaptation really changed the sense of its original story. The director of the film changed it into a romance film and made it more sensual.

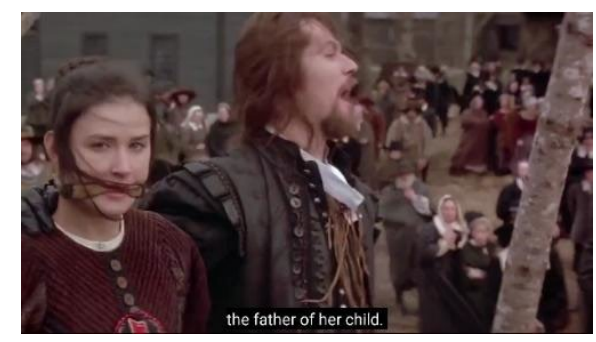

Fig 12. Dimmesdale's confession 


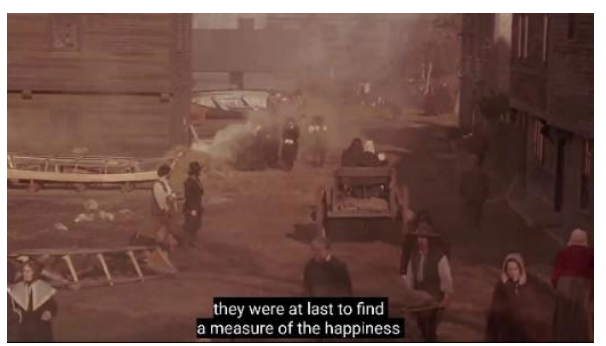

Fig 13. Hester, Dimmesdale, and Pearl left Boston

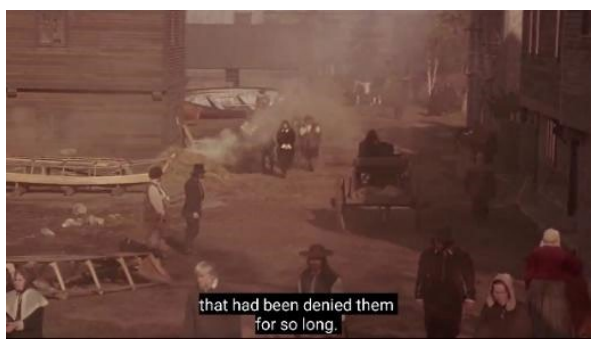

Fig 14. Hester, Dimmesdale, and Pearl left Boston

From those five scenes of The Scarlet Letter film adaptation, even though the meaning was somewhat not really changed, however, there was still another word that can attach to the symbol "A". Hence, the researchers believed that by employing Peirce's triadic model of sign; representamen, object, and interpretant, the researchers could analyze how another meaning appears within the text, the researchers found that the representamen of those scenes is an embroidered badge of letter "A" stitched in gold and scarlet on Hester Prynne's bosom because that was the form which sign took (11). For its object, it was Hester who fell in lust at the first sight and madly in love with Dimmesdale because that was what reflected by the sign (9). Thus, the interpretant which means the significance delivered by the representamen about the object which was unknown in advance (9), was the letter " $A$ " on Hester's bosom that stood for "Ardor"; a strong or intense feeling of love or enthusiasm for someone or something which was the representation of Hester in this film.

\subsection{The Infidelity of The Scarlet Letter}

After being analyzed by Peirce's theory of semiotics, the researchers found out that in the novel on the one hand the symbol 'A ' referred to 'Adultery', on the other hand it referred to 'Ability" because Hester proved herself that she could be useful for others beyond her label as an adulterer. Yet, in the film, it showed that the ' $A$ ' started with 'Adultery' until the story stepped further showing Hester who was madly in love with Dimmesdale and willing to do anything for him which ultimately resulted in the shifted significance of symbol 'A ' became 'Ardor'; a strong or intense feeling of love or enthusiasm for someone or something which was the representation of Hester in this film. In another word, literature-to-film adaptation The Scarlet Letter is 
unfaithful and straying away from its original text; which is the novel. It could be understood that to fulfill the market needs, the film industry has to change to follow the mainstream, which was having a story ended with a happy love life.

\section{Conclusion}

In conclusion, lust indeed the reason all the things that befall to Hester. Nevertheless, the novel and film have their own ways in responding to those circumstances. The novel focuses on how the symbol 'A' can be a good signification, Nathaniel wanted to portray a woman who does not easily give up whatever the conditions she faces; from weakness to strength. Yet, the film seems to get carried away by the love life of Hester which resulted in Hester's character who does not care about her punishment as long as she can be together with Arthur Dimmesdale. 


\section{References}

1. Snyder MH. Analyzing Literature-to-Film Adaptation: A Novelist's Exploration and Guide. 1st ed. New York: The Continuum International Publishing Group; 2011.

2. Hawthorne N. The Scarlet Letter United State of America: THE NEW AMERICAN LIBRARY OF WORLD LITERATURE; 1959.

3. Woodlief A. Background on Puritan Theology. [Online].; 2010. Available from: https://archive.vcu.edu/english/engweb/puritantheology.htm.

4. İSAOĞLU IH. A FREUDIAN PSYCHOANALYTIC ANALYSIS OF NATHANIEL HAWTHORNE'S THE SCARLET LETTER. The Journal of Academic Social Science Studies. 2015;: p. 499-511.

5. Wang Y. A Representative of the New Female-Analyzing Hester Prynne's Feminist Consciousness in The Sacrlet Letter. Journal of Language Teaching and Research. 2010;: p. 893-897.

6. Sang Y. An Analysis of Hester's Hypocrisy in The Sacrlet Letter. Journal of Language Teaching and Research. 2010;: p. 447-450.

7. Magfirah S. Analyzing Social Aspects in The Scarlet Letter Novel by Nathaniel Hawthorne (A Generic Structuralism Approach). ELITE: English and Literature Journal. 2017;: p. 29-36.

8. Xin-Yu Z. A Comparative Analysis of The Scarlet Letter from Fiction to Movie. 3rd International Conference on E-commerce and Contemporary Economic Development (ECED 2017). 2017;: p. 222-224.

9. Leeds-Hurwitz W. Semiotics and Communication: Sign, Codes, Cultures New Jersey: Lawrence Erlbaum Assciates, Publishers; 1993.

10. Halina YMS, Andreas T. The Semiotic Perspective of Peirce and Saussure: A Brief Comparative Study. ELSEVIER. 2014 October;: p. 4-8.

11. Chandler D. Semiotics for Beginners England: University of Wales; 2000.

12. Kamthan P. A FRAMEWORK FOR THE PRAGMATIC QUALITY OF Z SPECIFICATION. Interntional Journal of Software Engineering and Knowledge. 2006 February; XVI(05).

13. Heidenheimer AJ, Heclo H, Adams CT. Comparative Public Policy New York: St. Martin's Press; 1983. 